\title{
Article \\ Exploring Suitable Biochar Application Rates with Compost to Improve Upland Field Environment
}

\author{
Se-Won Kang ${ }^{\mathbb{D}}$, Jin-Ju Yun, Jae-Hyuk Park and Ju-Sik Cho *(D) \\ Department of Agricultural Life Sciences \& Interdisciplinary Program in IT-Bio Convergence System, \\ Sunchon National University, Suncheon 57922, Korea; kangsw@scnu.ac.kr (S.-W.K.); \\ wlswn6511@hanmail.net (J.-J.Y.); jaehyuk0309@naver.com (J.-H.P.) \\ * Correspondence: chojs@scnu.ac.kr; Tel.: +82-61-750-3297
}

Citation: Kang, S.-W.; Yun, J.-J.; Park, J.-H.; Cho, J.-S. Exploring Suitable Biochar Application Rates with Compost to Improve Upland Field Environment. Agronomy 2021, 11, 1136. https://doi.org/10.3390/ agronomy11061136

Academic Editor: Sara Di Lonardo

Received: 11 May 2021

Accepted: 31 May 2021

Published: 2 June 2021

Publisher's Note: MDPI stays neutral with regard to jurisdictional claims in published maps and institutional affiliations.

Copyright: (c) 2021 by the authors. Licensee MDPI, Basel, Switzerland. This article is an open access article distributed under the terms and conditions of the Creative Commons Attribution (CC BY) license (https:// creativecommons.org/licenses/by/ $4.0 /)$.
Abstract: A field experiment was carried out to investigate crop productivity, emissions of carbon dioxide $\left(\mathrm{CO}_{2}\right)$ and nitrous oxide $\left(\mathrm{N}_{2} \mathrm{O}\right)$, and soil quality of an upland field treated with compost and varying rates of biochar (BC) derived from soybean stalks during crop growing periods in a corn and Chinese cabbage rotation system. Compost was supplemented with BC derived from soybean stalks at varying rates of 5, 10, 15, and $20 \mathrm{tha}^{-1}$ (BC5, BC10, BC15, and BC20, respectively); the control (BC0) area was untreated. Our results reveal that crop productivity and emissions of $\mathrm{CO}_{2}$ and $\mathrm{N}_{2} \mathrm{O}$ varied significantly with the biochar application rate. Moreover, irrespective of the biochar application rate, crop productivity was improved after BC application as compared to the control treatment area, by $11.2-29.3 \%$ (average $17.0 \pm 8.3 \%$ ) for corn cultivation and $10.3-39.7 \%$ (average $27.8 \pm 12.7 \%$ ) for Chinese cabbage cultivation. Peak emissions of $\mathrm{CO}_{2}$ and $\mathrm{N}_{2} \mathrm{O}$ were mainly observed in the early period of crop cultivation, whereas low $\mathrm{CO}_{2}$ and $\mathrm{N}_{2} \mathrm{O}$ emissions were determined during the fallow period. Compared to the control area, significant differences were obtained for $\mathrm{CO}_{2}$ emissions produced by the different biochar application rates for both crops. During the two cropping periods, the overall $\mathrm{N}_{2} \mathrm{O}$ emission was significantly decreased with $\mathrm{BC} 5, \mathrm{BC} 10$, $\mathrm{BC} 15$, and $\mathrm{BC} 20$ applications as compared to the control, ranging from 11.1 to $13.6 \%, 8.7$ to $15.4 \%$, 23.1 to $26.0 \%$, and 15.0 to $19.6 \%$, respectively (average $16.9 \%$ decrease in the corn crop period and $16.3 \%$ in the Chinese cabbage crop period). Soil quality results after the final crop harvest show that bulk density, soil organic carbon (SOC), $\mathrm{pH}$, and cation exchange capacity (CEC) were significantly improved by biochar application, as compared to the control. Taken together, our results indicate that compost application supplemented with biochar is potentially an appropriate strategy for achieving high crop productivity and improving soil quality in upland field conditions. In conclusion, appropriate application of biochar with compost has the concomitant advantages of enriching soil quality for long-term sustainable agriculture and reducing the use of inorganic fertilizers.

Keywords: biochar; compost; crop productivity; soil quality; rotation system

\section{Introduction}

Fertilizers are substances applied to the soil for nourishing plants and benefitting their growth. Based on their convenience and efficacy, chemical fertilizers are important materials that contribute to increasing the crop yield and securing stable crop productivity [1]. However, overuse of chemical fertilizers on agricultural land results in an imbalance of nutrients in the soil and lowers the soil organic matter content [2]. In particular, a decrease in the organic matter content of agricultural soils degrades the physical, chemical, and biological properties of the soil, thereby reducing soil fertility [3]. Consequently, the continued use of chemical fertilizers affects crop production by decreasing the soil quality [4].

Chemical fertilizers are regularly applied to maintain the stability of crop production in South Korea, resulting in a considerable increase in usage, from 233 in 2010 to $268 \mathrm{~kg} \mathrm{ha}^{-1}$ in 2016 [5]. Currently, the use of chemical fertilizers per hectare in South Korea is classified 
as high, as compared to usage in the major Organization for Economic Cooperation and Development (OECD) countries. In addition, intensive summer rainfall and frequent tillage further deteriorate the soil quality, resulting in the need for better soil management [6].

Biochar can be produced at different temperatures without or with limited oxygen conditions through the pyrolysis of organic wastes such as straw, stalk, manure, shells, and sludge $[1,7,8]$. Biochar has been applied for various purposes, including improvement in soil fertility and carbon sequestration and mitigation of climate change, and in renewable energy production [9-11]. In addition, biochar is very useful in the agricultural environment due to its inherent unique characteristics, including $\mathrm{pH}$, cation exchange capacity (CEC), specific surface area, and bulk density, when produced under different pyrolysis methods [12-14]. In particular, in the field of agriculture, there is an abundant interest to examine the effect of biochar application on soil improvement and crop productivity. Furthermore, biochar application is also being explored for the reduction in greenhouse gas emissions, such as methane $\left(\mathrm{CH}_{4}\right)$ and $\mathrm{N}_{2} \mathrm{O}$, which are largely associated with global warming $[13,15-17]$. Hence, over the long term, it is necessary to study the application of biochar as a method to maintain the soil environment and soil quality and also to lower the global warming potential of agricultural practices.

In the current study, the combination of biochar and compost application was investigated for improving crop productivity and for conservation of the soil quality, in a corn and Chinese cabbage crop rotation cultivation system in an upland field. Compost contains various nutrients essential for crop production, and it is therefore very important for providing a nutrient supply and improving soil fertility. In particular, livestock manure compost contains several essential nutrients including nitrogen, phosphorus, and potassium. Hence, its application as a fertilizer to replace chemical fertilizers, and as an organic fertilizer, can contribute to the improvement in soil structure. This approach has positive effects on the crop yield and soil quality and, additionally, reduces emissions of greenhouse gases, thereby encouraging the conservation of the agricultural environment. Finally, this study evaluated the crop productivity and soil factors including soil bulk density, soil organic carbon (SOC), $\mathrm{pH}, \mathrm{CEC}, \mathrm{CO}_{2}$ (soil respiration), and $\mathrm{N}_{2} \mathrm{O}$ emission as they are affected by different biochar application rates with compost.

\section{Materials and Methods}

\subsection{Preparation of Biochar and Compost}

Soybean stalks were used as the raw feedstock to produce biochar. The stalks were dried in an oven at $75^{\circ} \mathrm{C}$ for $48 \mathrm{~h}$ before conversion to biochar. Soybean stalk biochar (BC) was produced through pyrolysis under anaerobic, oxygen-limited conditions in a covered stainless-steel container and pyrolyzed in a furnace supplied with injection of a continuous flow of $\mathrm{N}_{2}$ gas. The furnace controller was programmed to increase the internal biomass chamber to $600{ }^{\circ} \mathrm{C}$ at the rate of $3{ }^{\circ} \mathrm{C} \mathrm{min}-1$, after which the peak temperature was sustained for $1 \mathrm{~h}$. The properties of $\mathrm{BC}$ are presented in Table 1.

Table 1. Properties of biochar derived from soybean stalk used in this study.

\begin{tabular}{|c|c|c|c|c|c|c|c|c|c|c|c|}
\hline \multirow[t]{2}{*}{ BET SA * } & \multirow[t]{2}{*}{ Yield } & \multirow{2}{*}{$\mathrm{pH}$} & \multicolumn{5}{|c|}{ Elemental Composition } & \multicolumn{4}{|c|}{ Molar Ratio } \\
\hline & & & $\mathrm{C}$ & $\mathbf{H}$ & $\mathbf{O}$ & $\mathbf{N}$ & S & $\mathrm{H} / \mathrm{C}$ & $\mathrm{O} / \mathrm{C}$ & $(\mathrm{O}+\mathrm{N}) / \mathrm{C}$ & $(\mathrm{O}+\mathrm{N}+\mathrm{S}) / \mathrm{C}$ \\
\hline$\left(\mathrm{m}^{2} \mathrm{~g}^{-1}\right)$ & $(\%)$ & $\left(1: 10 \mathrm{H}_{2} \mathrm{O}\right)$ & & & $(\%)$ & & & & & & \\
\hline \multirow{3}{*}{127} & 30.5 & 10.5 & 74.1 & 2.37 & 21.7 & 1.37 & 0.41 & 0.38 & 0.22 & 0.24 & 0.24 \\
\hline & \pm & \pm & \pm & \pm & \pm & \pm & \pm & \pm & \pm & \pm & \pm \\
\hline & 1.76 & 0.01 & 0.32 & 0.07 & 0.33 & 0.02 & 0.00 & 0.01 & 0.00 & 0.00 & 0.00 \\
\hline
\end{tabular}

Livestock manure compost was applied as the raw compost used in this study, comprising cow and poultry manures along with sawdust. The total carbon (TC), total nitrogen (TN), $\mathrm{P}_{2} \mathrm{O}_{5}, \mathrm{~K}_{2} \mathrm{O}, \mathrm{CaO}$, and $\mathrm{MgO}$ contents of the compost were $41.8 \%, 1.82 \%, 2.06 \%, 1.80 \%$, $1.69 \%$, and $0.28 \%$, respectively. 


\subsection{Site Description and Design}

The field experiment was conducted from March 2016 to November 2016 on an upland field ( $34^{\circ} 56^{\prime} 21^{\prime \prime} \mathrm{N}, 127^{\circ} 33^{\prime} 53^{\prime \prime}$ E) located at Sepung-ri, Gwangyang-eup, Gwangyang-si, Jeollanam-do, South Korea. The study field cultivated corn and Chinese cabbage through a crop rotation system, where Chinese cabbage was transplanted after corn harvesting. The experimental site experienced a mild oceanic climate with mean annual precipitation of $1615 \mathrm{~mm}$, and a mean temperature of $13.9^{\circ} \mathrm{C}$ (Figure 1). This region has a total possible mean sunshine duration of $12.2 \mathrm{~h}$ and mean sunshine duration of $5.7 \mathrm{~h}$. The field soil was a sandy loam having a bulk density of $1.30 \mathrm{Mg} \mathrm{m}^{-3}$, $\mathrm{pH}$ of 5.31 , electrical conductivity (EC) of $0.27 \mathrm{dS} \mathrm{m}^{-1}$, organic matter $(\mathrm{OM})$ of $26.5 \mathrm{~g} \mathrm{~kg}^{-1}$, TN of $1.74 \mathrm{~g} \mathrm{~kg}^{-1}$, and CEC of $8.65 \mathrm{cmol}_{\mathrm{C}} \mathrm{kg}^{-1}$.

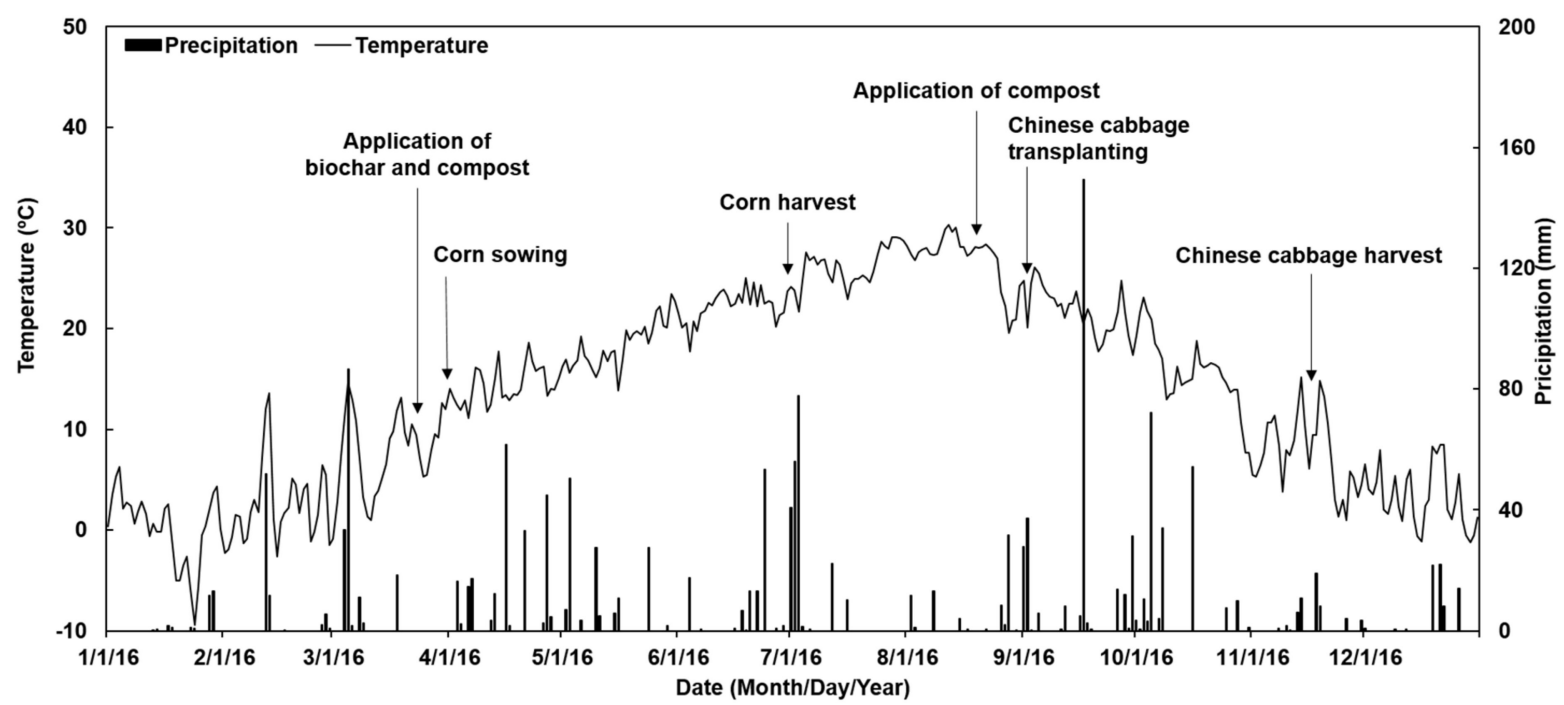

Figure 1. The mean temperature, daily precipitation, and field management activity during crop cultivation.

The treatment conditions included the application of $\mathrm{BC}$ at varying rates of $0,5,10$, 15, and $20 \mathrm{t} \mathrm{ha}^{-1}$ (BC0 (control), BC5, BC10, BC15, and BC20, respectively). The compost applied was the same for all treatment groups $\left(10 \mathrm{t} \mathrm{ha}^{-1}\right)$. Prior to sowing of corn, $\mathrm{BC}$ and compost were simultaneously sprayed on the field; thereafter, only compost was applied to the field before Chinese cabbage transplanting. The experiment was conducted in a randomized complete block design with a factorial arrangement and three replications. A total of 15 plots, each measuring $4 \mathrm{~m}^{2}$, were used during the experiment. Plots were separated by $0.25 \mathrm{~m}$, and each replicate was separated by $0.25 \mathrm{~m}$ to avoid an edge effect.

Corn was the first crop sowed in each plot on 25 March 2016 and was harvested on 1 July 2016. The second crop, Chinese cabbage, was transplanted into each plot on 2 September 2016 and harvested on 18 November 2016.

\subsection{Soil Sampling and Analysis}

Soil samples from each treatment plot were collected after final crop harvesting. Samples were collected from the surface layer $(15 \mathrm{~cm}$ depth), air dried, and passed through a $2 \mathrm{~mm}$ mesh. The physicochemical properties of the sieved soils were analyzed by applying standard methods [18].

\subsection{Measurement of $\mathrm{CO}_{2}$ and $\mathrm{N}_{2} \mathrm{O}$}

The monitoring of $\mathrm{CO}_{2}$ and $\mathrm{N}_{2} \mathrm{O}$ fluxes was achieved using a static chamber. Gas sampling was performed between 10 and 11 a.m. every 7 days. Gas samples were collected using a syringe, at 0,20 , and $40 \mathrm{~min}$ after chamber closure. The $\mathrm{CO}_{2}$ and $\mathrm{N}_{2} \mathrm{O}$ levels were simultaneously analyzed on a gas chromatograph (GC-2014, Shimadzu, Japan) equipped with a flame ionization detector (FID) and an electron capture detector (ECD), with the protocol performed as described in the manufacturer's manual. During gas analysis, the 
temperature was maintained at $55^{\circ} \mathrm{C}$ for the column, $100{ }^{\circ} \mathrm{C}$ for the injector, and $230{ }^{\circ} \mathrm{C}$ for the detector in the FID; in the ECD, temperatures were $50^{\circ} \mathrm{C}$ for the column and $310^{\circ} \mathrm{C}$ for the detector. The $\mathrm{CO}_{2}$ and $\mathrm{N}_{2} \mathrm{O}$ flux amounts were calculated using the following equation [19] (1), where $\mathrm{F}$ is $\mathrm{CO}_{2}$ and $\mathrm{N}_{2} \mathrm{O}$ flux, $\varrho$ is $\mathrm{CO}_{2}$ and $\mathrm{N}_{2} \mathrm{O}$ density, $\mathrm{V}$ is volume of chamber $\left(\mathrm{m}^{3}\right), \mathrm{A}$ is area of chamber $\left(\mathrm{m}^{2}\right), \Delta \mathrm{c} / \Delta \mathrm{t}$ is average increase in gas concentration, and $\mathrm{T}$ is $273+$ mean temperature in the chamber $\left({ }^{\circ} \mathrm{C}\right)$ :

$$
\mathrm{F}=\varrho \times(\mathrm{V} / \mathrm{A}) \times(\Delta \mathrm{c} / \Delta \mathrm{t}) \times(273 / \mathrm{T})
$$

The total $\mathrm{CO}_{2}$ and $\mathrm{N}_{2} \mathrm{O}$ fluxes for the entire crop cultivation were computed as described in [19] (2), where $\mathrm{Ri}$ is the rate of $\mathrm{CO}_{2}$ or $\mathrm{N}_{2} \mathrm{O}$ emission in the sampling interval, Di is the number of days in the sampling interval, and $n$ is the number of sampling intervals:

$$
\text { Total } \mathrm{CO}_{2} \text { and } \mathrm{N}_{2} \mathrm{O} \text { flux }=\sum_{i}^{n}(\mathrm{Ri} \times \mathrm{Di})
$$

\subsection{Statistical Analysis of Data}

Statistical analyses of all data, including crop, soil, and greenhouse gases, were performed by applying the JMP software with SAS (version 14.2). The mean values were measured as an average of three replicates, and the standard deviation was obtained from the result. Efficacy of the treatments subsequent to biochar application rates on parameters measured (including crop productivity, fluxes of $\mathrm{CO}_{2}$ and $\mathrm{N}_{2} \mathrm{O}$, and soil characteristics) was evaluated using one-way analysis of variance (ANOVA), and comparison of the treatments was obtained by Tukey's test. Tukey's test was used for mean separation at a 95\% confidence level. Regression analyses (linear vs. polynomial) were performed to determine the associations of soil bulk density, SOC, $\mathrm{pH}$, and CEC. All figures were drawn using Sigma plot 12.5 (SYSTAT Software Inc., San Jose, CA, USA).

\section{Results}

\subsection{Crop Productivity}

Results of the field-based experiment to evaluate varying rates of biochar application on the growth of corn and Chinese cabbage reveal that the effects were more pronounced on the second crop (Chinese cabbage) than the first crop (corn), as presented in Figure 2.

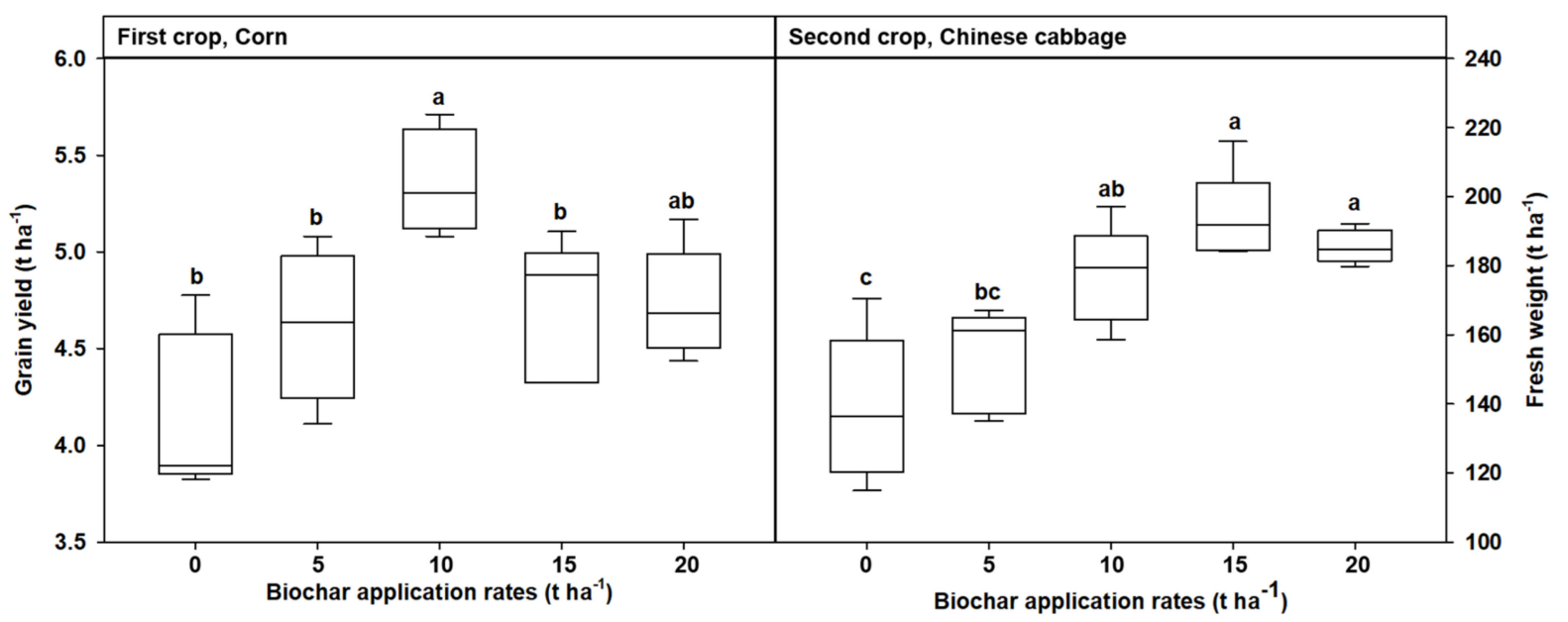

Figure 2. Characteristics of crop growth under different biochar application rates. Error bars represent standard deviations $(n=3)$. Different letters indicate significant differences among treatments at $5 \%$ probability level according to Tukey's test.

The mean corn grain yields obtained at BC0 (control), BC5, BC10, BC15, and BC20 treatments were $4.15,4.61,5.36,4.70$, and $4.73 \mathrm{t} \mathrm{ha}^{-1}$, respectively. Relative to the control treatment, increases in the corn grain yields were 11.2\% (BC5), 29.3\% (BC10), 13.3\% (BC15), and $14.0 \%$ (BC20). The fresh weight of Chinese cabbage obtained was highest with BC15 
and $\mathrm{BC} 20$ treatments; this weight was $33.8-40.0 \%, 21.3-26.7 \%$, and $4.8-9.5 \%$ higher than cabbages grown under $\mathrm{BC} 0, \mathrm{BC} 5$, and $\mathrm{BC} 10$ treatment conditions, respectively.

\subsection{Changes in $\mathrm{CO}_{2}$ and $\mathrm{N}_{2} \mathrm{O}$ Emissions}

Alterations in the gas emission rates during the crop growing period and the cumulative flux of $\mathrm{CO}_{2}$ and $\mathrm{N}_{2} \mathrm{O}$ during the crop growing and fallow periods are presented in Figures 3 and 4 .

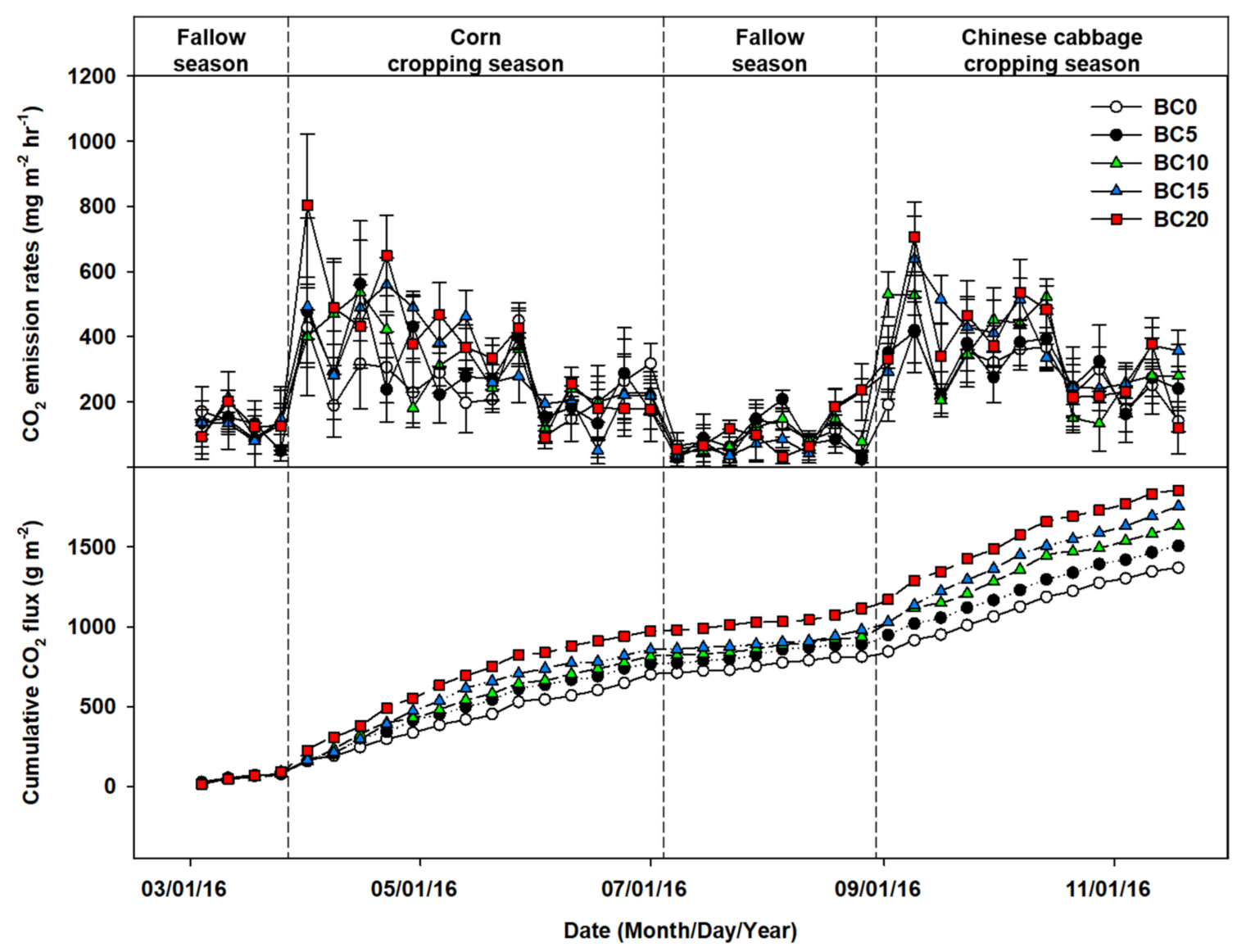

Figure 3. Changes in the $\mathrm{CO}_{2}$ emission rate and cumulative $\mathrm{CO}_{2}$ flux under different biochar application rates during crop cultivation. Error bars represent standard deviations $(n=3)$.

Overall, $\mathrm{CO}_{2}$ emission rates during the sampling period tended to increase with the increasing rate of biochar application. In particular, differences in $\mathrm{CO}_{2}$ emission rates between crop growing and fallow periods were remarkable (Figure 3). Regardless of the biochar application rates, the $\mathrm{CO}_{2}$ emission rate ranged from 50.6 to $803 \mathrm{mg} \mathrm{m}^{-2} \mathrm{~h}^{-1}$ during the corn growing period, and 121 to $706 \mathrm{mg} \mathrm{m}^{-2} \mathrm{~h}^{-1}$ during the Chinese cabbage growing period. The pattern of the $\mathrm{CO}_{2}$ emission rate for the first crop period for all treatments showed a rapid increase until 7 days after sowing, and a gradual decrease thereafter until corn harvesting. Similarly, for the second crop, the pattern of the $\mathrm{CO}_{2}$ emission rate in all treatments showed a rapid increase until 14 days after transplanting; thereafter, there was a gradual decrease in the $\mathrm{CO}_{2}$ emission until harvesting of the Chinese cabbage. In the growing periods for both corn and Chinese cabbage, the average rates of $\mathrm{CO}_{2}$ emission for the various treatments were 260 and 276 (BC0), 292 and 306 (BC5), 308 and 344 (BC10), 328 and 384 (BC15), and 374 and 367 (BC20) $\mathrm{mg} \mathrm{m}^{-2} \mathrm{~h}^{-1}$, respectively.

In addition, we also investigated changes in the $\mathrm{N}_{2} \mathrm{O}$ emission rates under different biochar applications during the crop cultivation period (Figure 4). Regardless of biochar application rates, the $\mathrm{N}_{2} \mathrm{O}$ emission rate ranged from 1.35 to $517 \mu \mathrm{g} \mathrm{m}^{-2} \mathrm{~h}^{-1}$ during the corn growing period, and 16.1 to $447 \mu \mathrm{g} \mathrm{m}^{-2} \mathrm{~h}^{-1}$ during the Chinese cabbage growing 
period. The $\mathrm{N}_{2} \mathrm{O}$ emission rates in the corn and Chinese cabbage growing periods increased to peak levels (411-517 $\mu \mathrm{g} \mathrm{m}^{-2} \mathrm{~h}^{-1}$ range) at 14 days after sowing of the corn crop, and in the range 306-447 $\mu \mathrm{g} \mathrm{m}^{-2} \mathrm{~h}^{-1}$ at 21 days after Chinese cabbage transplantation. Thereafter, the $\mathrm{N}_{2} \mathrm{O}$ emission rate in both crop growing periods gradually decreased until harvesting.

During the two fallow periods, the emission rates of $\mathrm{CO}_{2}$ and $\mathrm{N}_{2} \mathrm{O}$ were in the range of 24.2-236 mg m $\mathrm{m} \mathrm{h}^{-2} \mathrm{~h}^{-1}$ and 2.52-77.2 $\mu \mathrm{g} \mathrm{m}^{-2} \mathrm{~h}^{-1}$, respectively, for all treatment groups. These results show relatively small variations, compared to variations obtained in the crop growing periods.

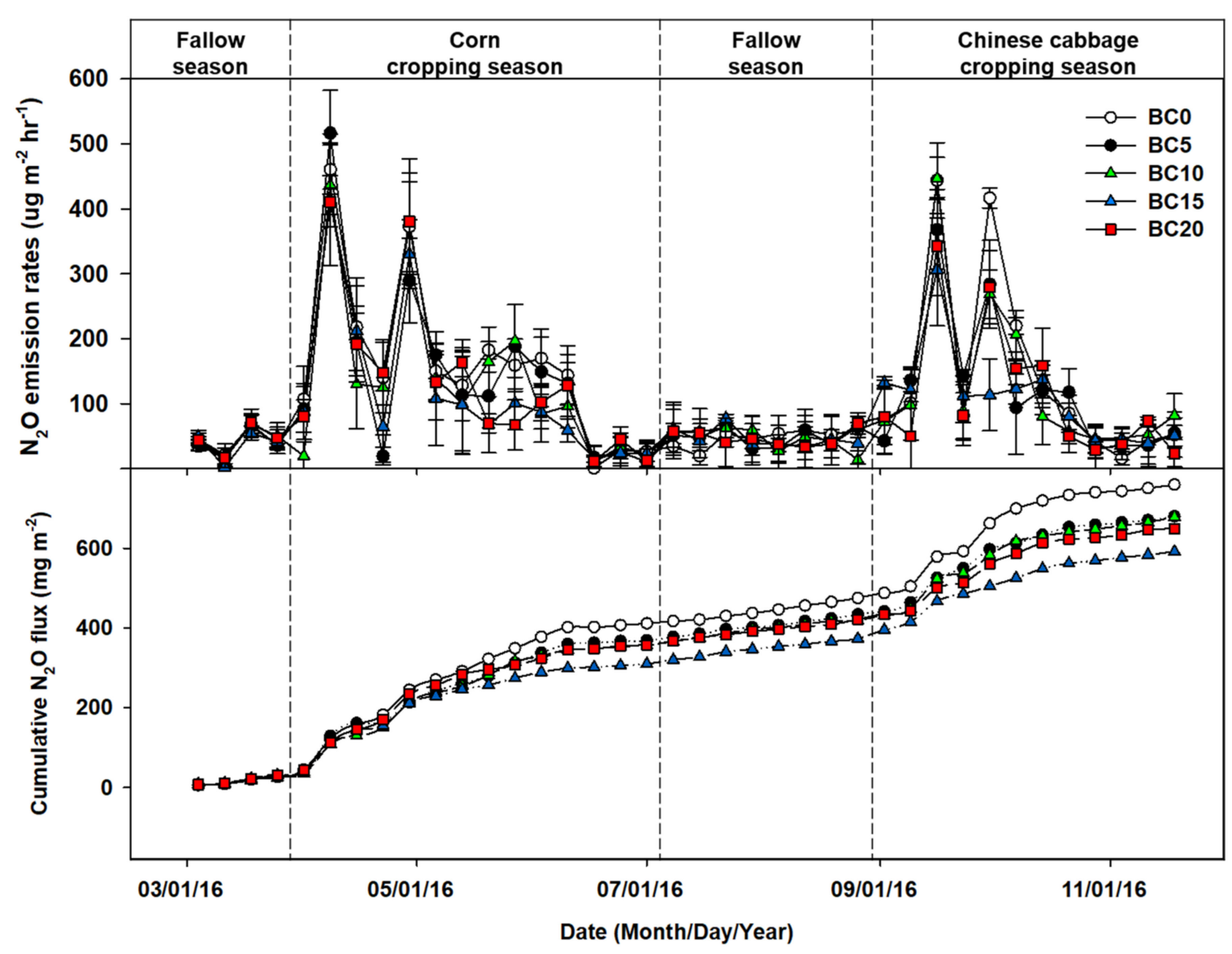

Figure 4. Changes in the $\mathrm{N}_{2} \mathrm{O}$ emission rate and cumulative $\mathrm{N}_{2} \mathrm{O}$ flux under different biochar application rates during crop cultivation. Error bars represent standard deviations $(n=3)$.

\subsection{Total Fluxes of $\mathrm{CO}_{2}$ and $\mathrm{N}_{2} \mathrm{O}$}

The total fluxes of $\mathrm{CO}_{2}$ and $\mathrm{N}_{2} \mathrm{O}$ showed significant differences between the biochar application treatments and control (Table 2). In addition, total $\mathrm{CO}_{2}$ and $\mathrm{N}_{2} \mathrm{O}$ fluxes were significantly higher during the crop growing periods than the fallow periods. In this study, regardless of treatment conditions, the annual total fluxes of $\mathrm{CO}_{2}$ and $\mathrm{N}_{2} \mathrm{O}$ ranged from 43.9 to $47.5 \%$ and 47.7 to $53.2 \%$, respectively, for the corn growing period, 11.9 to $14.7 \%$ and 12.6 to $14.9 \%$, respectively, for fallow periods, and 39.9 to $44.2 \%$ and 34.1 to $39.7 \%$, respectively, for the Chinese cabbage growing period. The $\mathrm{BC} 20$ treatment during the corn growing period showed a significantly greater total $\mathrm{CO}_{2}$ flux and a lower total $\mathrm{N}_{2} \mathrm{O}$ flux than other $\mathrm{BC}$ treatments. Similar to results obtained during the corn growing period, emissions of $\mathrm{CO}_{2}$ and $\mathrm{N}_{2} \mathrm{O}$ in the Chinese cabbage growing period were significantly influenced by the biochar application rate, with the total $\mathrm{N}_{2} \mathrm{O}$ flux tending to increase with increasing biochar concentrations. In contrast, total fluxes of $\mathrm{CO}_{2}$ and $\mathrm{N}_{2} \mathrm{O}$ were not significantly affected by the biochar applications during the fallow periods. 
Table 2. Total flux of $\mathrm{CO}_{2}$ and $\mathrm{N}_{2} \mathrm{O}$ under different biochar application rates during crop cropping, fallow season, and annual.

\begin{tabular}{|c|c|c|c|c|c|c|c|c|}
\hline \multirow[t]{2}{*}{ Treatment } & \multicolumn{2}{|c|}{ Corn Cropping Season } & \multicolumn{2}{|c|}{ Fallow Season } & \multicolumn{2}{|c|}{$\begin{array}{l}\text { Chinese Cabbage } \\
\text { Cropping Season }\end{array}$} & \multicolumn{2}{|c|}{ Annual } \\
\hline & $\mathrm{CO}_{2}$ & $\mathrm{~N}_{2} \mathrm{O}$ & $\mathrm{CO}_{2}$ & $\mathrm{~N}_{2} \mathrm{O}$ & $\mathrm{CO}_{2}$ & $\mathrm{~N}_{2} \mathrm{O}$ & $\mathrm{CO}_{2}$ & $\mathrm{~N}_{2} \mathrm{O}$ \\
\hline & $\left(\mathrm{g} \mathrm{m}^{-2}\right)$ & $\left(\mathrm{mg} \mathrm{m}^{-2}\right)$ & $\left(\mathrm{g} \mathrm{m}^{-2}\right)$ & $\left(\mathrm{mg} \mathrm{m}^{-2}\right)$ & $\left(\mathrm{g} \mathrm{m}^{-2}\right)$ & $\left(\mathrm{mg} \mathrm{m}^{-2}\right)$ & $\left(\mathrm{g} \mathrm{m}^{-2}\right)$ & $\left(\mathrm{mg} \mathrm{m}^{-2}\right)$ \\
\hline $\mathrm{BC} 0$ & $611 \pm 80.7 b^{*}$ & $385 \pm 21.1 \mathrm{a}$ & $201 \pm 16.6 a$ & $90.4 \pm 9.52 \mathrm{a}$ & $557 \pm 8.8 \mathrm{c}$ & $285 \pm 5.8 \mathrm{a}$ & $1369 \pm 79.8 c$ & $760 \pm 32.7 \mathrm{a}$ \\
\hline BC5 & $688 \pm 17.4 \mathrm{ab}$ & $342 \pm 11.5 \mathrm{ab}$ & $201 \pm 27.2 \mathrm{a}$ & $91.9 \pm 20.2 \mathrm{a}$ & $616 \pm 70.7 b c$ & $246 \pm 11.4 \mathrm{ab}$ & $1505 \pm 69.9 \mathrm{bc}$ & $680 \pm 20.5 b$ \\
\hline BC10 & $724 \pm 50.4 \mathrm{ab}$ & $325 \pm 13.5 \mathrm{ab}$ & $214 \pm 20.6 \mathrm{a}$ & $93.6 \pm 12.3 \mathrm{a}$ & $693 \pm 69.4 \mathrm{abc}$ & $260 \pm 18.9 \mathrm{ab}$ & $1631 \pm 59.4 \mathrm{ab}$ & $679 \pm 16.2 \mathrm{~b}$ \\
\hline $\mathrm{BC15}$ & $771 \pm 43.7 \mathrm{ab}$ & $285 \pm 41.7 \mathrm{~b}$ & $208 \pm 26.4 \mathrm{a}$ & $88.3 \pm 4.8 \mathrm{a}$ & $775 \pm 63.1 \mathrm{a}$ & $219 \pm 23.4 \mathrm{~b}$ & $1754 \pm 91.0 \mathrm{a}$ & $592 \pm 41.8 \mathrm{c}$ \\
\hline BC20 & $879 \pm 122.2 \mathrm{a}$ & $327 \pm 42.7 \mathrm{ab}$ & $235 \pm 34.8 \mathrm{a}$ & $93.8 \pm 16.8 \mathrm{a}$ & $739 \pm 25.9 \mathrm{ab}$ & $229 \pm 25.2 \mathrm{~b}$ & $1853 \pm 131.7 \mathrm{a}$ & $650 \pm 12.6 \mathrm{bc}$ \\
\hline$p$-value & 0.012 & $0.0 \angle 3$ & 0.502 & 0.986 & 0.003 & 0.010 & $<0.001$ & $<0.001$ \\
\hline
\end{tabular}

* Different letters within the same column indicate significant differences, as determined by Tukey's test with $p<0.05$.

\subsection{Soil Properties}

The bulk density, SOC, $\mathrm{pH}$, and CEC soil properties were investigated for each randomly selected collection site subsequent to the final crop harvest in 2016 (Figure 5). The overall changes in soil properties were significant among the tested soils. Regardless of the biochar application rate, the bulk density, $\mathrm{SOC}, \mathrm{pH}$, and $\mathrm{CEC}$ of the treated soils ranged from 1.10 to $1.32 \mathrm{Mg} \mathrm{m}^{-3}, 15.5$ to $19.5 \mathrm{~g} \mathrm{~kg}^{-1}, 5.57$ to 6.07 , and 8.4 to $11.1 \mathrm{cmol}_{\mathrm{c}} \mathrm{kg}^{-1}$, respectively. Compared to the control soil, the lowest decrease in bulk density was observed for the $\mathrm{BC} 20$ treatment, followed sequentially by $\mathrm{BC} 10, \mathrm{BC} 15$, and $\mathrm{BC} 5$ treatments. SOC was greater in the BC20-treated soil than in the control soil. Similarly, $\mathrm{pH}$ and CEC were determined to be increased with increasing biochar application rate. The SOC, $\mathrm{pH}$, and CEC for the BC20 treatment soil were, respectively, $16.5 \%, 7.2 \%$, and $22.1 \%$ greater than values obtained for the $\mathrm{BC} 0$-treated soil.

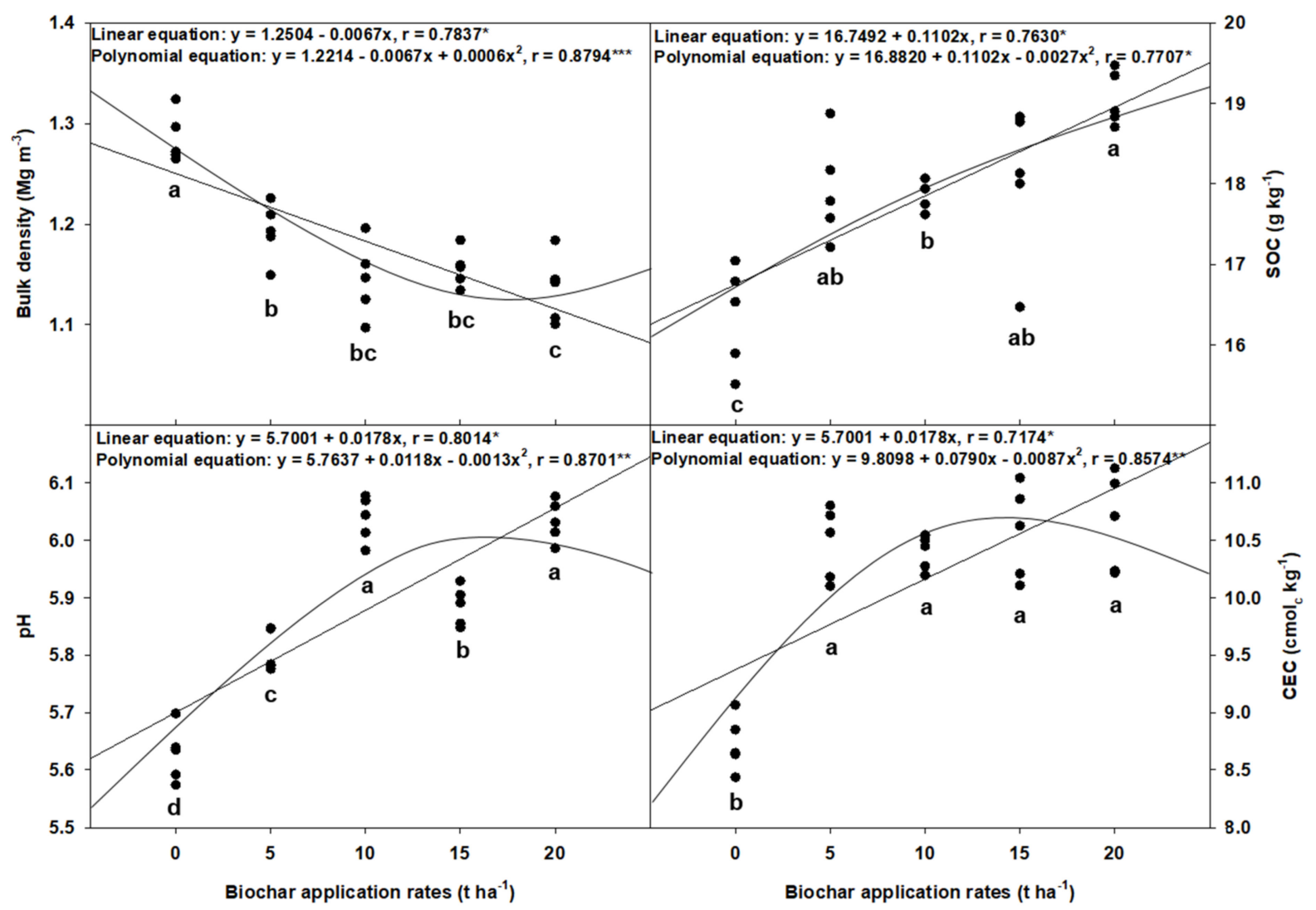

Figure 5. Soil properties after field harvest under different biochar application rates. Different letters indicate significant differences among treatments at $5 \%$ probability level according to Tukey's test. ${ }^{* * *},{ }^{* * *}$ denote not significant and significant differences at the 5,1 , and $0.1 \%$ levels, respectively. 
The correlations among each BC treatment level for soil properties are presented based on linear and polynomial equations (Figure 5). The bulk density, $\mathrm{pH}$, and CEC correlations under different biochar application rates and for both types of equations show that the $r$ value of the polynomial equation is greater than the linear equation value; however, the SOC $r$ values were notably not different. Regardless, no significant difference was obtained in the CEC results for different biochar applications.

\section{Discussion}

The positive effects of biochar application on the cultivation of crops are well known. It has been reported that the application of biochar to soil increases the crop productivity by improving soil physicochemical properties $[1,7,17,20]$. Several researchers have reported that biochar application rates of 5 to $50 \mathrm{t} \mathrm{ha}^{-1}$ are effective for growing crops [21]. However, the appropriate biochar application rate for improving crop productivity has not been clarified, since characteristics of the biochar produced vary according to the pyrolysis temperature, production method, and raw material. Thus, in the present study, we evaluated the effects of compost supplemented with different application rates of biochar, in a corn and Chinese cabbage rotation cultivation system. The results obtained should be useful in developing biochar application strategies that will maintain a sustainable resource cultivation agriculture system, preserve upland field environments, and secure long-term food production stability.

\subsection{The Effect of Biochar Application Rates on Crop Productivity}

Interestingly, subsequent to biochar application in the field soil, the highest productivities of the first and second crops were recorded at different conditions in this study.

Compared to the control area, the corn grain yield following biochar application increased by $11.2-29.3 \%$, with the highest productivity obtained under the BC10 treatment. The biochar produced by agricultural byproducts generally has a high $\mathrm{pH}$ and EC, although slight variations are observed, depending on the pyrolysis temperature $[8,15,22]$. A high EC in soil can hinder the growth of crops and is a feature that appears in facility cultivation sites where chemical fertilizers have been applied for a long duration. Once biochar with a high EC is incorporated, the soil environment changes instantaneously. Such soil changes were thought to affect the initial growth period following the germination of corn. Mia et al. [23] reported that high biochar application rates result in poor plant growth due to salt stress related to the high EC of biochar. Similarly, Zhang et al. [24] applied biochar at 20 and $40 \mathrm{tha}^{-1}$ for corn cultivation. They reported a $7-14 \%$ increase in growth compared to the untreated areas, and a higher growth rate at biochar application of $20 \mathrm{t} \mathrm{ha}^{-1}$. Uzoma et al. [25] also reported higher corn yield after biochar application, in the order $15 \mathrm{tha}^{-1}>20 \mathrm{tha}^{-1}>10 \mathrm{tha}^{-1}>0 \mathrm{tha}^{-1}$. These results indicate that crop productivity following biochar application differs according to the crop type, cropping period, and the period of biochar incorporation.

In the current study, the fresh weight of Chinese cabbage (the second crop produced after biochar application) increased by $10.3-39.7 \%$ compared to the BC 0 treatment. These results may be attributed to the gradual stabilization of the treated soil conditions during Chinese cabbage cultivation, unlike during corn cultivation. Our results are consistent with previous reports [26-29]. For example, Major et al. [30] found no yield effect from biochar application during the first year of maize cultivation, but they did find a significant yield increase after 2-4 years of biochar application. In a greenhouse vegetable system, Zhang et al. [16] also reported a significant effect on the annual vegetable yield after biochar application of $10 \mathrm{t}, 20 \mathrm{t}$, and $40 \mathrm{t} \mathrm{ha}^{-1}$, along with $\mathrm{N}$ fertilizer. In addition, Zhang et al. [31] reported a 11.9-35.4\% increase in maize yields in biochar-treated areas (applied at $40 \mathrm{tha}^{-1}$ ) as compared to control areas, regardless of the investigation period or fertilizer type. Contrarily, Rogovska et al. [32] reported significant increases in maize yields during the first year of biochar application, but no subsequent biochar yield effect despite improved soil fertility, in the second year. It is also reported that biochar with a high $\mathrm{C} / \mathrm{N}$ ratio 
decreases the yields or biomass of crops due to an increase in the soil $\mathrm{N}$ fixing rate [33]. In our study, slight differences were obtained according to treatment conditions, but overall crop productivity was positively affected by biochar application, presumably through improved soil properties.

\subsection{The Effect of Biochar Application Rates on Emissions of $\mathrm{CO}_{2}$ and $\mathrm{N}_{2} \mathrm{O}$}

Previous studies have shown different effects of biochar application on $\mathrm{CO}_{2}$ and $\mathrm{N}_{2} \mathrm{O}$ emissions in upland soils; biochar application in an upland field can either affect [24] or not affect $\mathrm{CO}_{2}$ emissions [34]. In our observations, high levels of cumulative $\mathrm{CO}_{2}$ emissions were observed in the $\mathrm{BC} 15$ and $\mathrm{BC} 20$ treatment areas during both the corn and Chinese cabbage growing periods. Other studies have indicated that the increase in $\mathrm{CO}_{2}$ emissions observed after biochar treatment is possibly related to the decreased bulk density of the soil and the increased level of microbial activity [19,35]. Rogovska et al. [36] reported that regardless of manure application conditions, cumulative $\mathrm{CO}_{2}$ emissions under different biochar application rates were significantly increased due to enhanced SOC mineralization. In addition, $\mathrm{Lu}$ et al. [37] reported that four different rates of biochar applications in a chestnut plantation produced different $\mathrm{CO}_{2}$ emission levels: $\mathrm{BC} 10$ treatment $\left(10 \mathrm{tha}^{-1}\right)$ produced a higher cumulative $\mathrm{CO}_{2}$ level than other treatment groups $\left(0,2\right.$, and $\left.5 \mathrm{t} \mathrm{ha}^{-1}\right)$. In the current study, $\mathrm{CO}_{2}$ emissions obtained were slightly different according to the sampling period but showed an overall total $\mathrm{CO}_{2}$ flux increase with increasing biochar application; the highest annual $\mathrm{CO}_{2}$ was obtained subsequent to $\mathrm{BC} 20$ treatment. These results demonstrate that addition of biochar improves the physical properties of soil. Moreover, such improvements consequently increase soil aeration [17].

The main reason for the reduction in $\mathrm{N}_{2} \mathrm{O}$ following biochar application is reported to be related to microbial activity levels which, in turn, are a result of improved soil aeration, increased denitrification rates, and improvements resulting from alteration of $\mathrm{N}_{2} \mathrm{O}$ to $\mathrm{N}_{2}$ [38-40]. Several studies have reported the effects of biochar application on $\mathrm{N}_{2} \mathrm{O}$ emission in crop fields and also compared the application to effects from fertilizer treatment $[31,41,42]$. In our study, there was a reduction in $\mathrm{N}_{2} \mathrm{O}$ by biochar application; the annual $\mathrm{N}_{2} \mathrm{O}$ in biochar application treatments decreased by approximately $10.5-22.1 \%$ compared to the control treatment areas. In a previous study, Qin et al. [33] reported no significant difference in $\mathrm{N}_{2} \mathrm{O}$ reduction between biochar application and control treatment during rice cultivation (4 years); however, biochar amendment with 5, 10, and $20 \mathrm{t} \mathrm{ha}^{-1}$ resulted in a reduced $\mathrm{N}_{2} \mathrm{O}$ flux by $1.9-64.0 \%$ (average $30.4 \pm 17.8 \%$ ) compared to the decrease subsequent to chemical fertilizer treatment during the late rice season in 2012 and the early rice season in 2015. Lu et al. [37] also reported that as the biochar application rates increased, cumulative $\mathrm{N}_{2} \mathrm{O}$ efflux was significantly decreased. The low bulk density and specific characteristics of biochar are considered to affect the soil physicochemical properties, which may suppress $\mathrm{N}_{2} \mathrm{O}$ emission by improving soil aeration or increasing soil $\mathrm{pH}[43,44]$. One reason for the reduction in $\mathrm{N}_{2} \mathrm{O}$ emission is that biochar acts as a carbon source, thereby affecting denitrification [45,46]. Conversely, Shen et al. [47] reported that biochar application can be a nitrogen source, which cause $\mathrm{N}_{2} \mathrm{O}$ production. Additionally, Hawthorne et al. [35] reported a possibility that the $\mathrm{N}_{2} \mathrm{O}$ emission generated by biochar application increases due to the low relative soil saturation level and improved nitrification condition. In addition, $\mathrm{N}_{2} \mathrm{O}$ production can vary depending on the biochar production method, the application conditions, and the degree of weathering of biochar from the soil $[48,49]$. Hence, due to the complex interactions between biochar, soil, and other environmental factors, it is necessary to determine an appropriate biochar treatment strategy that considers the cultivation system to be used. Moreover, long-term studies are needed to further elucidate the mechanisms related to $\mathrm{CO}_{2}$ and $\mathrm{N}_{2} \mathrm{O}$ production.

\subsection{The Effect of Biochar Application Rates on Soil Quality}

The present study revealed a positive effect on soil quality, including improvements to soil bulk density, SOC, pH, and CEC, through biochar application. The biochar application 
rate in this study maintained a fertile soil condition over the crop rotation year. However, compared to the control treatment, the soil quality was clearly altered subsequent to different biochar applications, but the soil characteristics remained stable with increasing application rates.

Soil bulk density is the physical property that affects soil structure, water and nutrient transport, and soil aeration [42,50]. Several researchers have reported that biochar application decreases soil bulk density [51-53]. Niu et al. [54] and Kang et al. [6] observed that biochar application resulted in decreased soil bulk density in upland soils. Our results are similar to those of Zhang et al. [31], who reported that over a two-year period, maize field soil bulk density following biochar amendment $\left(0,20\right.$, and $\left.40 \mathrm{tha}^{-1}\right)$ was significantly decreased by $0.02-0.17 \mathrm{t} \mathrm{m}^{-3}$ after the conventional fertilization condition, and by $0.03-$ $0.20 \mathrm{t} \mathrm{m}^{-3}$ after the balanced fertilization condition, as compared to the control treatment. Azeem et al. [55] reported that in a mash bean-wheat crop system, biochar application $\left(0,5\right.$, and $\left.10 \mathrm{t} \mathrm{ha}^{-1}\right)$ decreased the soil bulk density regardless of fertilizer conditions, as compared to the control treatment. In addition, biochar application to upland soil increased the SOC, $\mathrm{pH}$, and CEC, thereby improving the nutrient availability rate and improving the stability of crop productivity. SOC is an index for improving agricultural productivity and soil resource utilization efficiency, which improves the soil fertility and productivity by increasing nutrient supply, water holding capacity, and microbial activity. As expected, our results indicate that biochar application to an upland field is associated with increased SOC, which is primarily due to the pyrolysis process producing a carbon-rich solid.

Soil $\mathrm{pH}$ and $\mathrm{CEC}$ are important indicators, and any alterations in these factors can influence the availability and retention of nutrients. Numerous studies have demonstrated that biochar application improves soil pH and CEC [15,26,47]. Major et al. [30] reported that soil $\mathrm{pH}$ after four years of a biochar treatment of $20 \mathrm{tha}^{-1}$ was higher than $\mathrm{pH}$ values obtained after biochar treatments of 0 and $8 \mathrm{t} \mathrm{ha}^{-1}$ at a depth of $30 \mathrm{~cm}$. Carter et al. [27] and Kelly et al. [56] also reported that the higher the rate of biochar application, the higher the cultivated soil $\mathrm{pH}$. Biochar is basically an alkaline substance with a high $\mathrm{pH}$ and therefore increases the soil $\mathrm{pH}$. In this study, increasing biochar application rates $(5,10,15$, and $20 \mathrm{t} \mathrm{ha}^{-1}$ ) significantly increased the resultant soil $\mathrm{pH}$ (by $0.18,0.41,0.26$, and 0.41 units, respectively). However, there was no straight-line relationship. This non-linear trend agrees with the results reported by Zhang et al. [31], which state that soil $\mathrm{pH}$ was higher in the order of $\mathrm{C} 1\left(20 \mathrm{t} \mathrm{ha}^{-1}\right)>\mathrm{C} 2\left(40 \mathrm{t} \mathrm{ha}^{-1}\right)>\mathrm{C} 0\left(0 \mathrm{t} \mathrm{ha}^{-1}\right)$ treatments. The current study also showed that the CEC results in soil were similar to the $\mathrm{pH}$ results under different biochar application rates. Soil CEC following biochar treatment was definitely higher than the control areas, presumably because biochar has a high specific surface area $[8,13]$; regardless, there was no significant difference in the CEC level based on the application rate. The results additionally reveal that alterations in the soil $\mathrm{pH}$ following biochar application are dependent on field conditions such as soil characteristics and crop growing period. In summary, biochar application for improving crop cultivation and soil fertility requires an appropriate application rate which needs to be determined in accordance with the prevailing environmental conditions.

\section{Conclusions}

Overall, biochar application rates were found to positively affect crop growth, soil quality, and soil respiration in an upland field environment. The higher biochar application rates contributed to changes in $\mathrm{N}_{2} \mathrm{O}$ emissions, with $\mathrm{N}_{2} \mathrm{O}$ emissions tending to gradually decrease. Following the biochar application, there were significant improvements in soil qualities, including improvements to bulk density, SOC, pH, and CEC. Similarly, at high application rates (10-20 $\mathrm{tha}^{-1}$ ), crop yields were increased for both corn and Chinese cabbage in the rotation system, after application of biochar to an upland field in South Korea. In particular, the effect of biochar application on crop growth revealed that the Chinese cabbage cultivation (second crop) benefited more than the corn cultivation (first crop). Considering the benefits resulting from the high application rates of biochar and 
compost application to an upland field, further studies are required to determine the usefulness of this procedure for increasing soil respiration and yields of corn and Chinese cabbage over the long term. Based on the results from the combined application of biochar and compost, the following points are deduced:

(1) Biochar application has the potential to improve soil conditions in an upland field;

(2) Crop productivity, soil quality, and greenhouse gas fluxes under different biochar application rates were monitored;

(3) Biochar application improved the bulk density, SOC, $\mathrm{pH}$, and CEC in field soil;

(4) Biochar application significantly reduces $\mathrm{N}_{2} \mathrm{O}$ emissions and increases soil respiration and crop productivity;

(5) Appropriate biochar application rates need to be defined for upland field environments.

Considering the benefits of biochar application, including an improved crop productivity and soil environment and replacing the use of inorganic fertilizers, we propose the use of an appropriate biochar application rate in a corn and Chinese cabbage rotation system in upland fields.

Author Contributions: S.-W.K., and J.-S.C. designed and conducted the experiment as well as writing the manuscript. J.-J.Y. and J.-H.P. conducted plant and soil analysis, $\mathrm{CO}_{2}$ and $\mathrm{N}_{2} \mathrm{O}$ measurement, and interpretation. All authors have read and agreed to the published version of the manuscript.

Funding: This work was supported by the Korea Institute of Planning and Evaluation for Technology in Food, Agriculture and Forestry (IPET) through the Technology Commercialization Support Program, funded by the Ministry of Agriculture, Food and Rural Affairs (MAFRA) (821007-02). Additionally, this work was supported by a grant from the Ministry of Science and ICT (MSIT) through the National Research Foundation (NRF) of Korea (NRF-2019R1A4A1029125). Moreover, this work was supported by the National Research Foundation of Korea (NRF) grant funded by the Korean government (MSIT) (NRF-2020R1I1A1A01058224). Additionally, this work was carried out with the support of the "Cooperative Research Program for Agriculture Science and Technology Development (Project No. PJ015568)" Rural Development Administration, Republic of Korea.

Institutional Review Board Statement: Not applicable.

Informed Consent Statement: Not applicable.

Data Availability Statement: Not applicable.

Conflicts of Interest: The authors declare no conflict of interest.

\section{References}

1. Ding, Y.; Liu, Y.; Liu, S.; Huang, X.; Li, Z.; Tan, X.; Zeng, G.; Zhou, L. Potential benefits of biochar in agricultural soils: A review. Pedosphere 2017, 27, 645-661. [CrossRef]

2. Lee, S.B.; Lee, C.H.; Jung, K.Y.; Park, K.D.; Lee, D.K.; Kim, P.J. Changes of soil organic carbon and its fractions in relation to soil physical properties in a long-term fertilized paddy. Soil Tillage Res. 2009, 104, 227-232. [CrossRef]

3. Bongiovanni, M.D.; Lobartini, J.C. Particulate organic matter, carbohydrate, humic acid contents in soil macro- and microaggregates as affected by cultivation. Geoderma 2006, 136, 660-665. [CrossRef]

4. Guo, J.H.; Liu, X.J.; Zhang, Y.; Shen, J.L.; Han, W.X.; Zhang, W.F.; Christie, P.; Goulding, K.W.T.; Vitousek, P.M.; Zhang, F.S. Significant acidification in major Chinsese croplands. Science 2010, 327, 1008-1010. [CrossRef] [PubMed]

5. Kang, S.W.; Lee, W.J.; Jeong, H.G.; Park, J.H.; Lee, J.H.; Yun, J.J.; Kim, S.Y.; Seo, D.C.; Cho, J.S. Effect of application levels of inorganic fertilizer with biochar on corn growth in an upland field. Korean J. Soil Sci. Fertil. 2018, 51, 547-554.

6. Kang, S.W.; Kim, S.H.; Park, J.H.; Seo, D.C.; Ok, Y.S.; Cho, J.S. Effect of biochar derived from barley straw on soil physicochemical properties, crop growth, and nitrous oxide emission in an upland field in South Korea. Environ. Sci. Pollut. Res. 2018, 25, 25813-25821. [CrossRef] [PubMed]

7. Palansooriya, K.N.; Ok, Y.S.; Awad, Y.M.; Lee, S.S.; Sung, J.K.; Koutsopyros, A.; Moon, D.H. Impacts of biochar application on upland agriculture: A review. J. Environ. Manag. 2019, 234, 52-64. [CrossRef]

8. Peng, X.; Ye, L.L.; Wang, C.H.; Zhou, H.; Sun, B. Temperature- and duration-dependent rice straw-derived biochar: Characteristics and its effects on soil properties of an Ultisol in southern China. Soil Tillage Res. 2011, 112, 159-166. [CrossRef]

9. Angst, T.E.; Six, J.; Reay, D.S.; Sohi, S.P. Impact of pine chip biochar on trace greenhouse gas emissions and soil nutrient dynamics in an annual ryegrass system in California. Agric. Ecosyst. Environ. 2014, 191, 17-26. [CrossRef] 
10. Mclennon, E.; Solomon, J.K.Q.; Neupane, D.; Davison, J. Biochar and nitrogen application rates effect on phosphorus removal from a mixed grass sward irrigated with reclaimed wastewater. Sci. Total. Environ. 2020, 715, 137012. [CrossRef]

11. Man, Y.; Wang, B.; Wang, J.; Slaný, M.; Yan, H.; Li, P.; El-Naggar, A.; Shaheen, S.M.; Rinkeble, J.; Feng, X. Use of biochar to reduce mercury accumulation in Oryza sativa L: A trial for sustainable management of historically polluted farmlands. Environ. Int. 2021, 153, 106527. [CrossRef] [PubMed]

12. Luo, X.; Liu, G.; Xia, Y.; Chen, L.; Jiang, Z.; Zheng, H.; Wang, Z. Use of biochar-compost to improve properties and productivity of the degraded coastal soil in the Yellow River Delta, China. J. Soils Sediments 2017, 17, 780-789. [CrossRef]

13. Martinsen, V.; Alling, V.; Nurida, N.L.; Mulder, J.; Hale, S.E.; Ritz, C.; Rutherford, D.W.; Heikens, A.; Breedveld, G.D.; Cornelissen, G. pH effects of the addition of three biochars to acidic Indonesian mineral soils. Soil Sci. Plant Nutr. 2015, 61, 821-834. [CrossRef]

14. Rajakumar, R.; Sankar, J. Biochar for sustainable agriculture-review. Int. J. Appl. Pure Sci. Agric. 2016, 2, $173-184$.

15. Sandhu, S.S.; Ussiri, D.A.N.; Kumar, S.; Chintala, R.; Papiernik, S.K.; Malo, D.D.; Schumacher, T.E. Analyzing the impacts of three types of biochar on soil carbon fractions and physiochemical properties in a corn-soybean rotation. Chemosphere 2017, 184, 473-481. [CrossRef]

16. Zhang, Y.; Wang, H.; Maucieri, C.; Liu, S.; Zou, J. Annual nitric and nitrous oxide emissions response to biochar amendment from an intensive greenhouse vegetable system in southeast China. Sci. Hortic. 2019, 246, 879-886. [CrossRef]

17. Major, J.; Lehmann, J.; Rondon, M.; Goodale, C. Fate of soil-applied black carbon: Downward migration, leaching and soil respiration. Glob. Chang. Biol. 2010, 16, 1366-1379. [CrossRef]

18. NIAST. Methods of Soil and Plant Analysis; National Institute of Agricultural Science and Technology, RDA: Suwon, Korea, 2000.

19. Kang, S.W.; Seo, D.C.; Cheong, Y.H.; Park, J.W.; Park, J.H.; Kang, H.W.; Park, K.D.; Ok, Y.S.; Cho, J.S. Effect of barley straw biochar application on greenhouse gas emissions from upland soil for Chinese cabbage cultivation in short-term laboratory experiments. J. Mt. Sci. 2016, 13, 259-702. [CrossRef]

20. Oliveira, F.R.; Patel, A.K.; Jaisi, D.P.; Adhikari, S.; Lu, H.; Khanal, S.K. Environmental application of biochar: Current status and perspectives. Bioresour. Technol. 2017, 246, 110-122. [CrossRef]

21. Major, J. Guideline on Practical Aspects of Biochar Application to Field Soil in Various Soil Management Systems; International Biochar Initiative: Westerville, OH, USA, 2010.

22. Genesio, L.; Milglietta, F.; Baronti, S.; Vaccari, F.P. Biochar increases vineyard productivity without affecting grape quality: Result from a four years field experiment in Tuscany. Agric. Ecosyst. Environ. 2015, 201, 20-25. [CrossRef]

23. Mia, S.; van Groenigen, J.W.; van de Voorde, T.F.J.; Oram, N.J.; Bezemer, T.M.; Mommer, L.; Jeffery, S. Biochar application rate affects biological nitrogen fixation in red clover conditional on potassium availability. Agric. Ecosyst. Environ. 2014, 91, 83-91. [CrossRef]

24. Zhang, A.; Liu, Y.; Pan, G.; Hussain, Q.; Li, L.; Zheng, J.; Zhang, X. Effect of biochar amendment on maize yield and greenhouse gas emissions from a soil organic carbon poor calcareous loamy soil from central China plain. Plant Soil 2012, 351, $263-275$. [CrossRef]

25. Uzoma, K.C.; Inoue, M.; Andry, H.; Fujimaki, H.; Zahoor, A.; Nishiihara, E. Effect of cow manure biochar on maize productivity under sandy soil condition. Soil Use Manag. 2011, 27, 205-212. [CrossRef]

26. Agegnehu, G.; Bass, A.M.; Nelson, P.N.; Bird, M.I. Benefits of biochar, compost and biochar-compost for soil quality, maize yield and greenhouse gas emissions in a tropical agricultural soil. Sci. Total. Environ. 2016, 543, 295-306. [CrossRef] [PubMed]

27. Carter, S.; Shackley, S.; Sohi, S.; Suy, T.B.; Haefele, S. The impact of biochar application on soil properties and plant growth of pot grown lettuce (Lactuca sativa) and cabbage (Brassica chinensis). Agronomy 2013, 3, 404-418. [CrossRef]

28. Liu, Z.; Chen, X.; Jing, Y.; Li, Q.; Zhang, J.; Huang, Q. Effects of biochar amendment on rapeseed and sweet potato yields and water stable aggregate in upland red soil. Catena 2014, 123, 45-51. [CrossRef]

29. Raboin, L.M.; Razafimahafaly, A.H.D.; Rabenharisoa, M.B.; Rabary, B.; Dusserre, J.; Becquer, T. Improving the fertility of tropical acid soils: Liming versus biochar application? A long term comparison in the highlands of Madagascar. Field Crop. Res. 2016, 199, 99-108. [CrossRef]

30. Major, J.; Rondon, M.; Molina, D.; Riha, S.J.; Lehmann, J. Maize yield and nutrition during 4 years after biochar application to a Colombian savanna oxisol. Plant Soil 2010, 333, 117-128. [CrossRef]

31. Zhang, D.; Pan, G.; Wu, G.; Kibue, G.W.; Li, L.; Zhang, X.; Zheng, J.; Zheng, J.; Cheng, K.; Joseph, S.; et al. Biochar helps enhance maize productivity and reduce greenhouse gas emissions under balanced fertilization in a rainfed low fertility inceptisol. Chemosphere 2016, 142, 106-113. [CrossRef] [PubMed]

32. Rogovska, N.; Laird, D.A.; Rathke, S.J.; Karlen, D.L. Biochar impact on Midwestern Mollisols and maize nutrient availability. Geoderma 2014, 230-231, 340-347. [CrossRef]

33. Qin, X.; Li, Y.; Wang, H.; Liu, C.; Li, J.; Wan, Y.; Gao, Q.; Fan, F.; Liao, Y. Long-term effect of biochar application on yield-scaled greenhouse gas emissions in a rice paddy cropping system: A four-year case study in south China. Sci. Total. Environ. 2016, 569-570, 1390-1401. [CrossRef]

34. Liu, X.; Zheng, J.; Zhang, D.; Cheng, K.; Zhou, H.; Zhang, A.; Li, L.; Joseph, S.; Smith, P.; Crowley, D.; et al. Biochar has no effect on soil respiration across Chinese agricultural soils. Sci. Total. Environ. 2016, 554-555, 259-265. [CrossRef] [PubMed]

35. Hawthorne, I.; Johnson, M.S.; Jassal, R.S.; Black, T.A.; Grant, N.J.; Smukler, S.M. Application of biochar and nitrogen influences fluxes of $\mathrm{CO}_{2}, \mathrm{CH}_{4}$ and $\mathrm{N}_{2} \mathrm{O}$ in a forest soil. J. Environ. Manag. 2017, 192, 203-214. [CrossRef] [PubMed] 
36. Rogovska, N.; Laird, D.; Cruse, R.; Fleming, P.; Parkin, T.; Meek, D. Impact of biochar on manure carbon stabilization and greenhouse gas emissions. Soil Sci. Soc. Am. J. 2011, 75, 871-879. [CrossRef]

37. Lu, X.; Li, Y.; Wang, H.; Singh, B.P.; Hu, S.; Luo, Y.; Li, J.; Xiao, Y.; Cai, X.; Li, Y. Response of soil greenhouse gas emissions to different application rates of biochar in a subtropical Chinese chestnut plantation. Agric. For. Meteorol. 2019, 271, 168-179. [CrossRef]

38. Cayuela, M.L.; Sanchez-Monedero, M.A.; Roig, A.; Hanley, K.; Enders, A.; Lehmann, J. Biochar and denitrification in soils: When, how much and why does biochar reduce $\mathrm{N}_{2} \mathrm{O}$ emission? Sci. Rep. 2013, 3, 1732-1739. [CrossRef]

39. Lai, W.Y.; Lai, C.M.; Ke, G.R.; Chung, R.S.; Chen, C.T.; Cheng, C.H.; Pai, C.W.; Chen, S.Y.; Chen, C.C. The effects of woodchip biochar application on crop yield, carbon sequestration and greenhouse gas emissions from soils planted with rice or leaf beet. J. Taiwan Inst. Chem. Eng. 2013, 44, 1039-1044. [CrossRef]

40. Nelissen, V.; Saha, B.K.; Ruysschaert, G.; Boeckx, P. Effect of different biochar and fertilizer types on $\mathrm{N}_{2} \mathrm{O}$ and $\mathrm{NO}$ emissions. Soil Biol. Biochem. 2014, 70, 244-255. [CrossRef]

41. Bass, A.M.; Bird, M.I.; Kay, G.; Muirhead, B. Soil properties, greenhouse gas emission and crop yield under compost, biochar and co-composted biochar in two tropical agronomic systems. Sci. Total. Environ. 2016, 550, 459-470. [CrossRef]

42. Tan, Z.; Lin, C.S.K.; Ji, X.; Rainey, T.J. Returning biochar to fields: A review. Appl. Soil Ecol. 2017, 116, 1-11. [CrossRef]

43. Wang, J.; Pan, X.; Liu, Y.; Zhang, X.; Xiong, Z. Effects of biochar amendment in two soils on greenhouse gas emissions and crop production. Plant Soil 2012, 360, 287-298. [CrossRef]

44. Zhang, A.; Cui, L.; Pan, G.; Li, L.; Hussain, Q.; Zhang, X.; Zheng, J.; Crowley, D. Effect of biochar amendment on yield and methane and nitrous oxide emissions from a rice paddy from Tai Lake plain, China. Agric. Ecosyst. Environ. 2010, 139, 469-475. [CrossRef]

45. Clough, T.J.; Condron, L.M.; Kammann, C.; Müller, C. A review of biochar and soil nitrogen dynamics. Agronomy 2013, 3, 275-293. [CrossRef]

46. Singla, A.; Inubushi, K. Effect of biochar on $\mathrm{CH}_{4}$ and $\mathrm{N}_{2} \mathrm{O}$ emission from soils vegetated with paddy. Paddy Water Environ. 2014, 12, 239-243. [CrossRef]

47. Shen, J.; Tang, H.; Liu, J.; Wang, C.; Li, Y.; Ge, T.; Jones, D.L.; Wu, J. Contrasting effects of straw of straw and straw-derived biochar amendments on greenhouse gas emissions within double rice cropping systems. Agric. Ecosyst. Environ. 2014, 188, 264-274. [CrossRef]

48. Spokas, K.A. Impact of biochar field aging on laboratory greenhouse gas production potentials. Glob. Chang. Biol. Bioenergy 2013, 5, 165-176. [CrossRef]

49. Lévesque, V.; Rochette, P.; Ziadi, N.; Dorais, M.; Antoun, H. Mitigation of $\mathrm{CO}_{2}, \mathrm{CH}_{4}$ and $\mathrm{N}_{2} \mathrm{O}$ from a fertigated horticultural growing medium amended with biochars and a compost. Appl. Soil Ecol. 2018, 126, 129-139. [CrossRef]

50. Arshad, M.A.; Lowery, B.; Grossman, B. Physical Tests for Monitoring Soil Quality. In Methods for Assessing Soil Quality; Doran, J.W., Jones, A.J., Eds.; SSSA: Madison, WI, USA, 1996; pp. 123-141.

51. Jien, S.H.; Wang, C.S. Effects of biochar on soil properties and erosion potential in a highly weathered soil. Catena 2013, 110, 225-233. [CrossRef]

52. Song, X.; Pan, G.; Zhang, C.; Zhang, L.; Wang, H. Effects of biochar application on fluxes of three biogenic greenhouse gases: A meta-analysis. Ecosyst. Health Sustain. 2016, 2, e01202. [CrossRef]

53. Rogovska, N.; Laird, D.A.; Karlen, D.L. Corn and soil response to biochar application and stover harvest. Field Crop. Res. 2016, 187, 96-106. [CrossRef]

54. Niu, Y.; Chen, Z.; Müller, C.; Zaman, M.M.; Kim, D.; Yu, H.; Ding, W. Yield-scaled $\mathrm{N}_{2} \mathrm{O}$ emissions were effectively reduced by biochar amendment of sandy loam soil under maize-Wheat rotation in the North China Plain. Atmos. Environ. 2017, 170, 58-70. [CrossRef]

55. Azeem, M.; Hayat, R.; Hussain, Q.; Ahmed, M.; Pan, G.; Tahir, M.I.; Imran, M.; Irfan, M.; Mehmood-ul-Hassan. Biochar improves soil quality and $\mathrm{N}_{2}$-fixation and reduces net ecosystem $\mathrm{CO}_{2}$ exchange in a dryland legume-cereal cropping system. Soil Tillage Res. 2019, 186, 172-182. [CrossRef]

56. Kelly, C.N.; Calderón, F.C.; Acosta-Martínez, V.; Mikha, M.M.; Benjamic, J.; Rutherford, D.W.; Rostad, C.E. Switchgrass biochar effects on plant biomass and microbial dynamics in two soils from different regions. Pedosphere 2015, 25, 329-342. [CrossRef] 